\title{
DELINEATION OF FLOOD RISK ZONES AND 3D MODELING IN TERENGGANU RIVER CATCHMENT USING GIS AND SWAT
}

\author{
Ibrahim Sufiyan, Razak Zakariya, Rosnan Yaacob \\ School of Marine and Environmental Sciences, Universiti Malaysia Terengganu, 21030 Kuala \\ Terengganu, Terengganu, Malaysia. \\ *Corresponding Author's Email: ibrahimsufiyan0@gmail.com
}

This is an open access article distributed under the Creative Commons Attribution License, which permits unrestricted use, distribution, and reproduction in any medium, provided the original work is properly cited.

\section{ARTICLE DETAILS}

\section{Article History:}

Received 12 November 2017 Accepted 12 December 2017 Available online 1 January 2018

\section{ABSTRACT}

\begin{abstract}
For many years, during the monsoon period the River (Sungai) Terengganu catchment in Malaysia has been flooding and causing flood risk problems to the inhabitants as well as the environment. This study uses the realtime simulation in ArcGIS 10.3 and 3D in ArcScene 10.3, and the variables obtained from the soil and water assessment tool SWAT such as the land use, soil and slope are the parameters measured to induce the flood. the application of soil water assessment tool (SWAT) has produced the demarcation or boundary called delineation of the whole Terengganu watershed. When certain portions of the Hydrologic response unit HRU; land use, soil or slope is changed due to temporal adjustment and climate change, then the model can predict zones of low, moderate and high flood risk. The 3D simulations appear to produce a visual model for decision-making, planning, management, and mitigation. The simulation helps in determining the extent of the flood by using animation in ArcScence 10.3, to visualize the simulated flood water level.
\end{abstract}

\section{KEYWORDS}

Flood risk, Delineation, GIS Modeling, SWAT, HRUs Parameters.

\section{INTRODUCTION}

The advent of remote sensing and Geographic Information System (GIS) has been given more consideration and useful detail on the mapping of land use/cover for the improvement of site selection and survey data designed for urban planning, agriculture, and industrial layout. The application helps in determining possible changes in land use/cover data with accuracy and precision. According to a study, most of the natural hazard such as flood and droughts are as a result of climate change globally, storms and flood are the most destructive natural disasters that cause death and loss of properties [1-4]. Therefore, flood risk is certain, defined by the existence of a threat to human beings, health, economy, infrastructure, and the environment [5]. The provision of accurate information about flood through 3D flood mapping is effective for risk management [6]. Flood is a serious hazard to human population especially the flash flood in any parts of the monsoon Asia [7-9].

According to a group of researchers, the use of satellite image for processing digital image such as the digital elevation model DEM provide visual and high graphics data for spatial interpolation and topographical analysis [10-13]. Flood risk can be a combination flood hazard events and the result of the flooding [14-16].

Flood is a serious natural disaster that constitutes a problem in Terengganu Malaysia. However, several efforts were made on how to devise ways of overcoming this natural risk in order to save lives and properties. The possible ways of flood protection can be active measures structurally through levees, reservoir or both. Based on a study, modeling is another wise idea and suitable measures for flood mitigation [17]. The land cover is being observed throughout the years in the study area and the flood during the monsoon season was correlated having tremendous effects that change the ecosystem and the ecological equilibrium for planning and economic purposes. The SWAT model is a long-term, continuous model simulation of the watershed. According to a research, it can be operated base on the daily step-by-step designed to predict the impact of management of water, pesticide, agricultural and chemical yield, sediment yield in the stream [18]. The model is useful for planning the physically based and computational efficiency and for accurate simulation. The ArcSWAT is designed as high-level spatial details that can allow catchment area to be divided into a number of subbasins and identify reservoirs. Land cover and land use changes affect local, regional and global climate processes. The development of computer-based technology in hydrological models made it easier and area of focus by researchers. A study shows watershed delineation based on DEM (Digital Elevation Model) is the primary concern and key step [19]. The success and accurate watershed delineation is the precondition of the major hydrologic components of runoff, sediment and water quality modeling with excellent result. There are two important methods of watershed delineation in SWAT model. One is the DEM-base method, based on the DEM of the study area and the second is the pre-defined method in which users can define the reaches and subbasins manually. But the best method adopted by many is DEM which has the high precision in slope terrains areas [7]. Watershed delineation is the specially based on the digital elevation models (DEMs) is one of the prerequisite to set up SWAT model. Attributes in GIS can be edited based on locations and hydrological connection to make the extraction realistic in the processes that made the requirement of the model set up. The burn-in algorithm was first used by Maidment of University of Texas, US. For this method, stream network available were used to process DEM.

The incorporation of HRUs non-spatial in SWAT has supported adaptation of virtually most of the watershed model. The recognition of size ranging from small field to entire river basins in HRUs within subwatershed is relevant because it keeps the model dependent by allowing soil and land use heterogeneously equal. However, there is a limitation in simulating waterways of grasses because of the channel routing is not simulated at HRU level [20]. According to a researcher, SWAT contains climatic inputs such as daily precipitation, maximum and minimum 
temperature, relative humidity, solar radiation, and wind speed [21].

\section{MATERIAL AND METHODS}

One of the issues in this study is on how to mitigate flood hazard in the entire watershed. During the high flow period of monsoon, this can be achieved by setting the reference points or benchmarks of different land use/cover and the role played by the HRUs in the Terengganu catchment. The two extremes will determine the occurrence of flood perhaps due to increase in the volume of the flow or because of land cover change at a certain period from the catchment area of Kuala Terengganu. The recent application of geographic information system GIS really helps in monitoring flood activities. The issue is how to overcome causalities if flooding occurs at a certain point in time. This study was based on available data obtained from the field. The capabilities of GIS are to calculate the risk analysis and alert public on the flood disaster. The monitoring of streams, rivers, drainages can be done through the simple hydrological concept of digital terrain model (DTM), and digital elevation model (DEM). However, this study focuses on the tropical environment (rainforest zone) where there is excessive rainfall and the wet season is greater than the dry season. The 3D visualization can provide essential models for decision making in Terengganu as well as the entire catchment in Malaysia. According to a study, the use of DEM with Geographic information system (GIS) can perform important hydrological functions such as calculation of slope, flow length, delineate watershed boundaries and stream network [22]. The data and material requirement for this study include; Automatic delineation (DEM based); ArcSWAT using grid water flow downhill, Grid cell-based approach, Boundaries created automatically, Create GIS layer which requires stream, subbasins, and outlets, Slope calculation, Point source.

The data required for watershed delineation includes; Land use distribution, Soil types (Local soil in the watershed)

\section{STUDY AREA}

The location of Kuala Terengganu has made it that almost every year there will be flood disaster within the catchment area. The amount of precipitation or humidity might increase due to increase in temperature or pressure. There are many issues cause for concern in this study but the major ones being the issue of flooding. The study area located in the eastern part of Peninsula Malaysia in the South China Sea with the area of the catchment around $2 \mathrm{~km} 2$ as illustrated in Figure 1 [23]. Based on a study, the study area is quite shallow with the deepest area around approximately $50 \mathrm{~m}$ and less than 50 nautical miles from the shore. The lower part has a gentle slope gradually deepening towards the open sea [24].

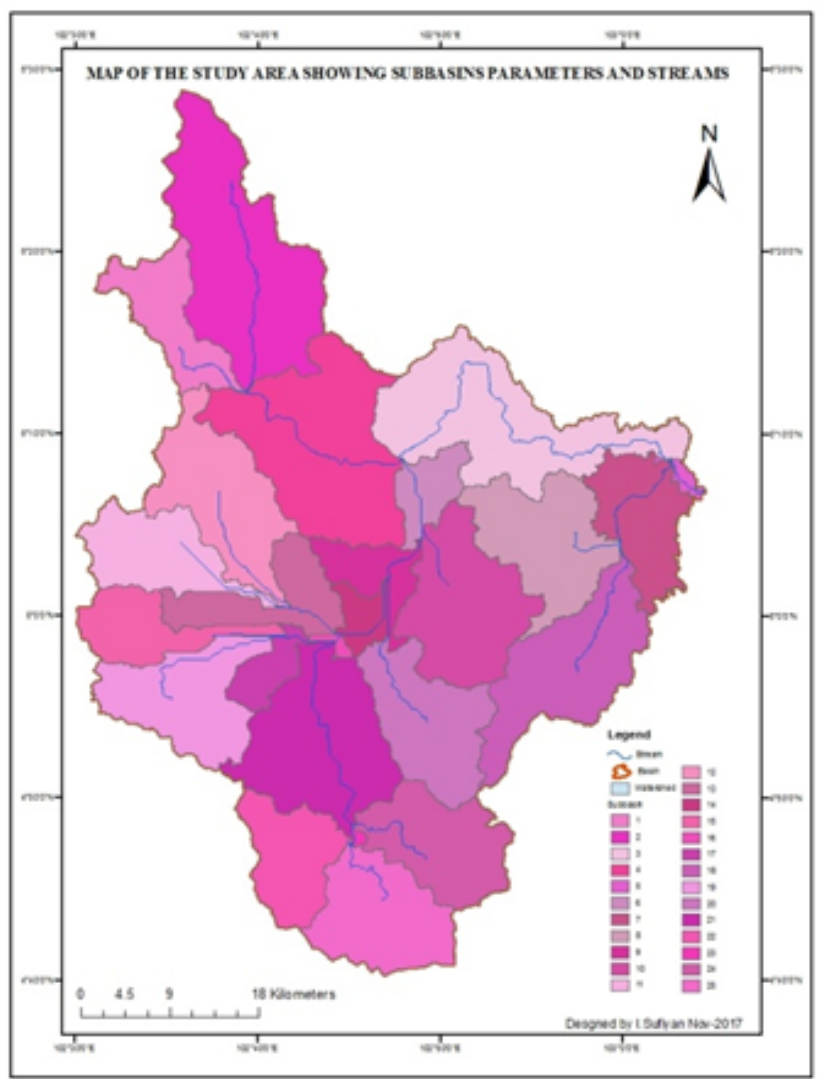

Figure 1: Study area location map
The modeling procedure includes; the shapefiles of the water base level made from the study area, Cropped digital elevation model DEM, Use of ArcGIS - ArcScene simulation, 3D Modeling

\section{RESULTS AND DISCUSSION}

\subsection{Delineation of watershed}

The result reported the elevation of the Terengganu catchment in meters after the watershed delineation is completed and the stream outlets are selected as in Figure 2a, b. The Table 1 below is the elevation result from the ArcSWAT delineation report.

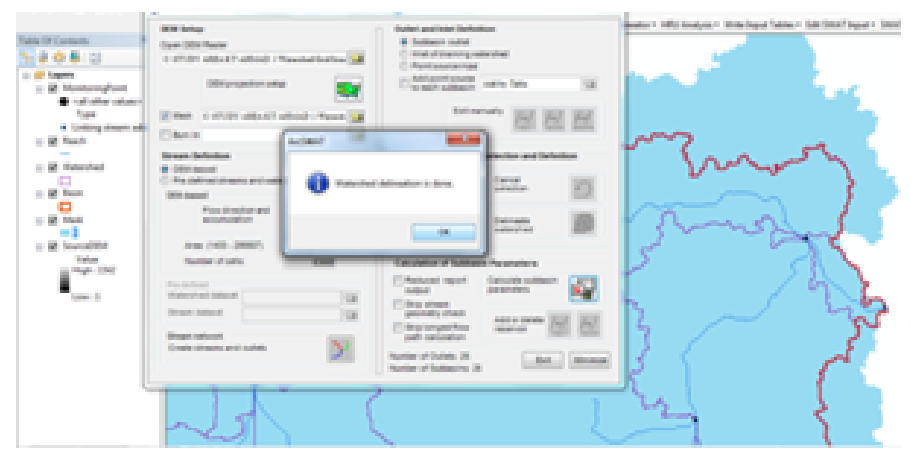

Figure 2a: Delineation completed successfully and stream outlet was defined

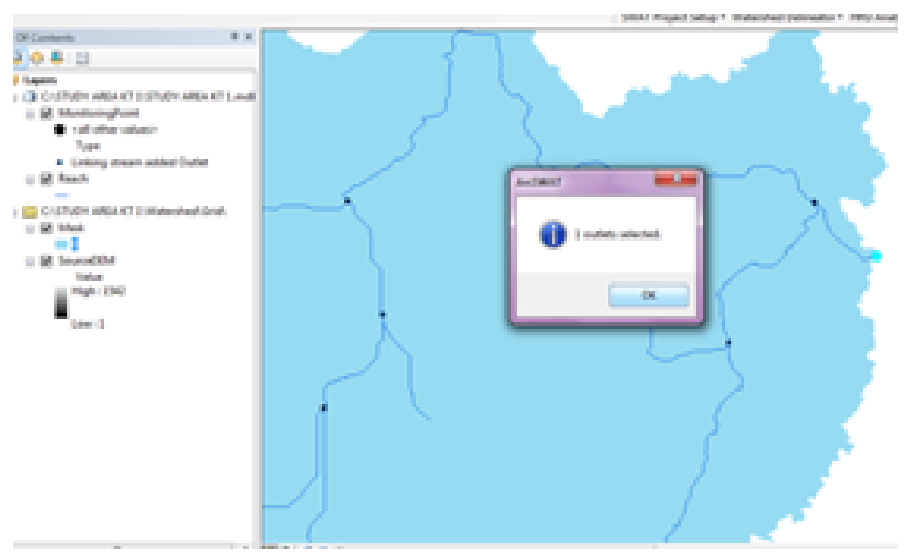

Figure 2b: Delineation completed successfully and stream outlet was defined

Table 1: Elevation result

\begin{tabular}{l}
\hline Elevation report for the watershed \\
01/01/0001 20:20:37 $\quad 06 / 11 / 2017$ \\
0:00:00
\end{tabular}

Statistics: All elevations reported in meters

Min. Elevation: 1

Max. Elevation: 1525

Mean. Elevation: 330.721614052833

\section{Std. Deviation: 258.058754270319}

The Figure 3 below, presents the boundaries of the delineated watershed of Terengganu River catchment. 


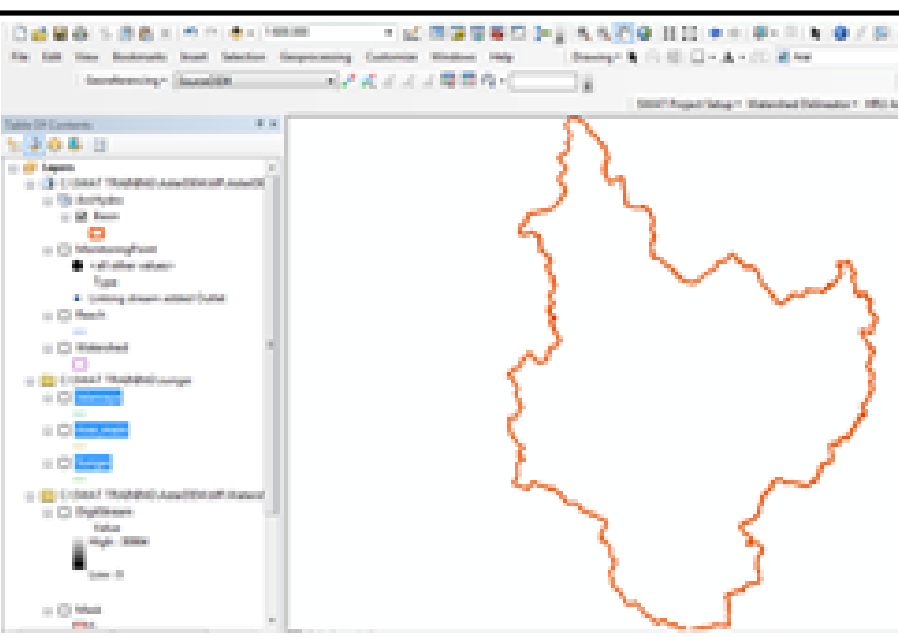

Figure 1: Study area location map

The stream network and the outlets are appended to the watershed to show how the water flows figure 4 . Each stream was defined by the subbasins parameter that supply water input to it Figure 5.

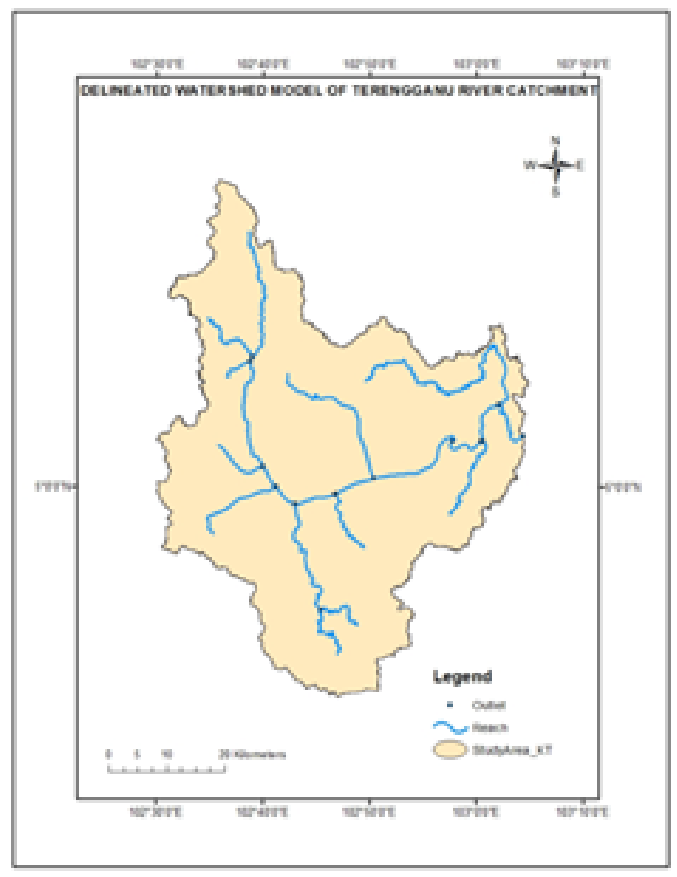

Figure 4: The stream network in the delineated watershed

\subsection{Calculation of Subbasins Parameters}

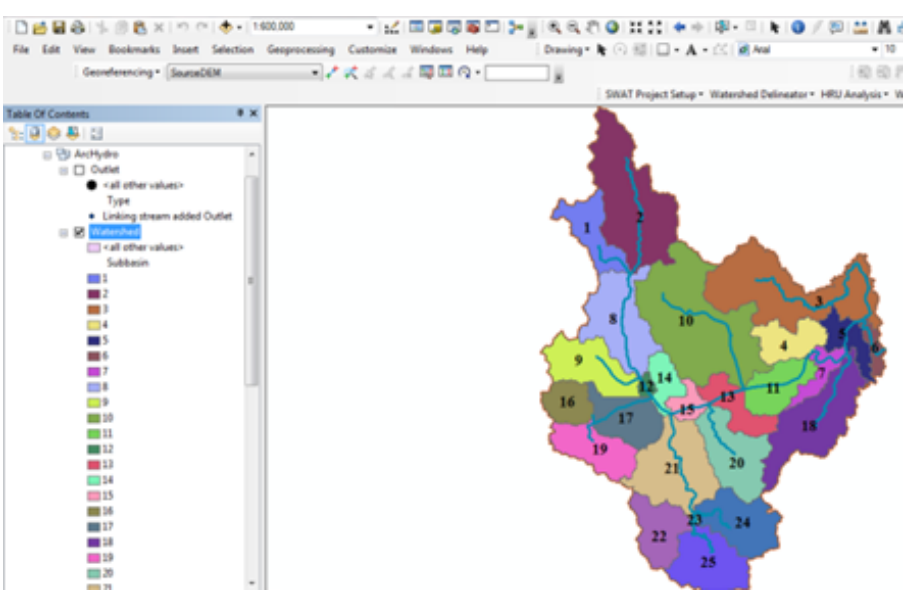

Figure 5: Subbasins parameters

The hydrologic response units (HRUs) are responsible for the creation of subbasins Parameters. There are about 25 different subbasins, with each have a distinct characteristic size, water volume, and a number of land use/cover, local soil types and slope units shown in Table 2 .
Table 2: Land use, soil and slope results

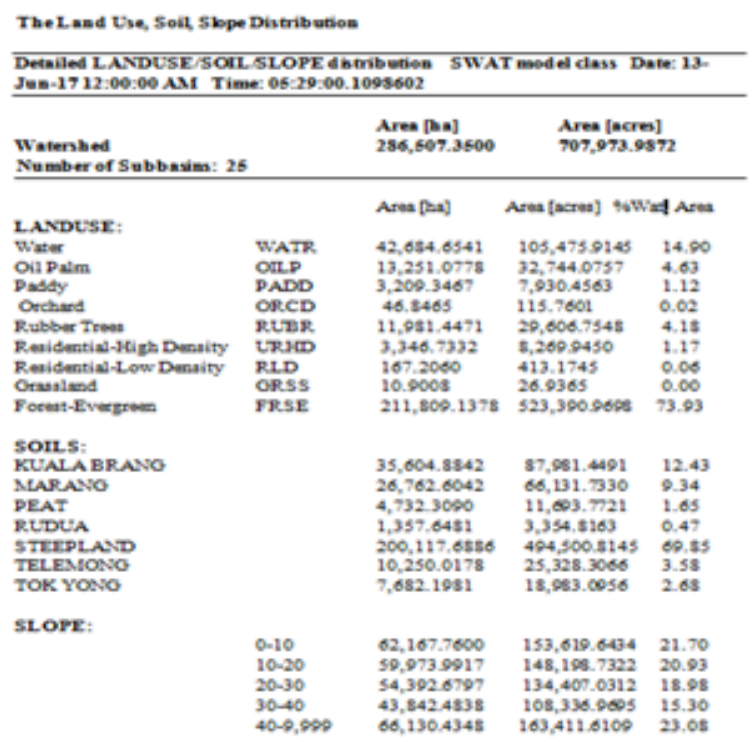

In other to define boundaries demarcated from the delineation, the flood risk digital elevation models DEM were developed as in figure 6. The 3D models help in the real-time simulation in the ArcScene. The result from the SWAT was obtained on 13th May 2017 at 05:29 pm with the total area of the watershed having $286,507.3500$ hectares or $707,973.9872$ acres. The total numbers of sub-basins obtained in Terengganu River catchment are 25 shown Figure 5, characterized by 305 numbers of Hydrologic Response Units (HRUs) as shown in Table 3 and 4. The threshold of 10/10/10 percent was chosen and selected to get the model fit and validation.

Table 3: Summary result from the catchment

\begin{tabular}{|c|l|c|c|}
\hline $\begin{array}{l}\text { Watershed Number } \\
\text { of Sub-basins: }\end{array}$ & Area [ha] & Area[acres] & Number of HRL's \\
\hline 25 & $286,507.3500$ & 707,9739872 & 305 \\
& & & \\
\hline
\end{tabular}

Table 4: Hydrologic Response Units result

Final HRE Report

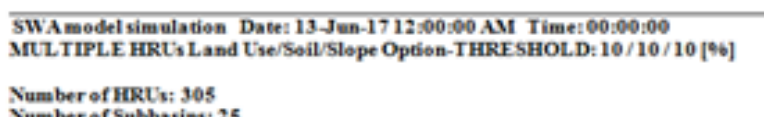

Number of Subbssin: 25

\begin{tabular}{|c|c|c|c|c|}
\hline \multicolumn{2}{|l|}{ Wateribed } & \multirow{2}{*}{$\begin{array}{l}\text { Area ha] } \\
286,507.3500 \\
\text { Avea [ha] }\end{array}$} & \multicolumn{2}{|l|}{$\begin{array}{l}\text { Area [acres] } \\
\text { 7xe7.973.9572 }\end{array}$} \\
\hline \multicolumn{2}{|l|}{ LANDCSE: } & & Area [acres] $56 W_{3}$ & Vat_Area \\
\hline Forest-Evergeen & FRSE & 218.004 .9972 & 538.700 .25987 & 7609 \\
\hline OAl Palm & OILP & $12,304.0858$ & 30,40401114 & 4.29 \\
\hline Rubbet Trees & RUBR & $13,513.3255$ & $33,392.1029 \quad 4$ & 4.72 \\
\hline Water & WATR & $41,136.8873$ & 101,65130541 & 1436 \\
\hline Retidensial-High Des & nsity URHD & 129.6177 & $320.2918 \quad 0$ & 0.05 \\
\hline Paddy & PADD & $1,418.8366$ & $3,506.0161$ & 0.50 \\
\hline \multicolumn{5}{|l|}{ son.s: } \\
\hline STEEPLAND & & $208,888.2877$ & $516,173.4034$ & 72.91 \\
\hline MARANO & & 23.010 .5513 & $56, \$ 60.2228$ & 803 \\
\hline KUALA BEAVG & & 36356.0535 & 598376261 & 1269 \\
\hline PEAT & & 2037.1739 & 5033.9585 & 0.71 \\
\hline RELEMONO & & 8.643 .5487 & $21,358.6411$ & 3.02 \\
\hline TOK YONG & & $7,571.7348$ & $18,710.1352$ & 2.64 \\
\hline \multicolumn{5}{|l|}{ SLOPE: } \\
\hline & $40.9,999$ & $70,109.7709$ & $173,244.7493$ & 24.47 \\
\hline & $30-40$ & $45,352.5699$ & $112,068.4679$ & 15.83 \\
\hline & $20-30$ & $56,084,6213$ & 138.5879036 & 19.58 \\
\hline & 10.20 & 62.309 .7811 & 153.970 .5845 & 21.75 \\
\hline & 0.10 & 52.650 .6068 & $130,102.2818$ & 18.38 \\
\hline
\end{tabular}

The digital elevation model DEM of the study area clearly depicts the slope which is lowest toward the north-Easter corner near the South China Sea. The 3D model in Figure 3 below, demonstrates the lowest water level zones 


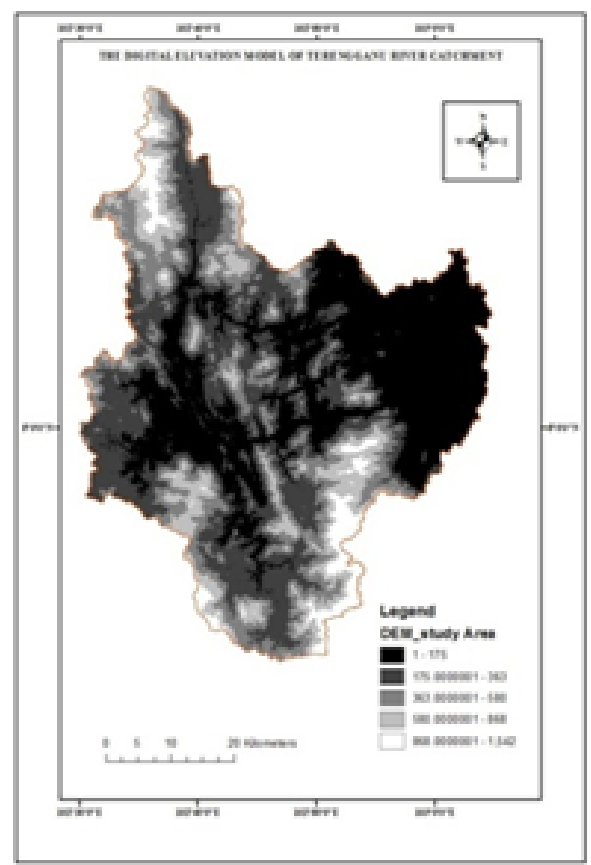

Figure 6: DEM of the study area

\subsection{D modeling of Terengganu catchment}

The 3D environment is used for ascertaining simulation of the areas liable to flood. The result shows that within the watershed, the stream flow was started at the lower elevated zones near the South China Sea then preceded to the interior of the catchment as shown in Figure 4.

\section{Lowest water level zone}

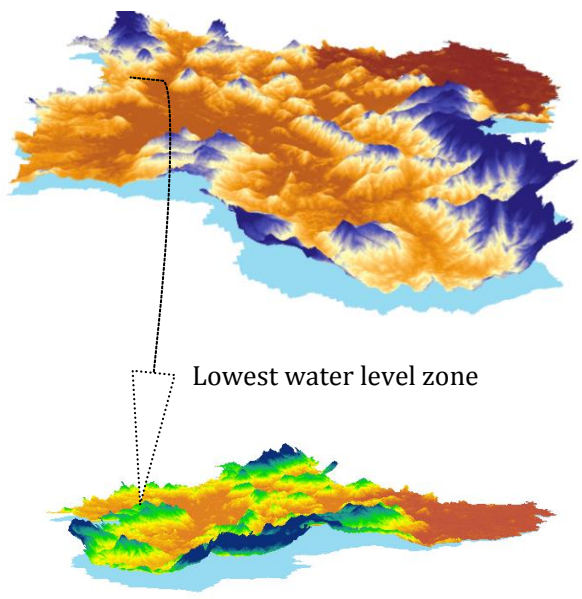

Figure 7: 3D Model design of the study area

\subsection{Simulation of Flood risk zoning}

The result of the simulation illustrates the flood risk zone into 5 categories. The risk analysis is necessary for planning and mitigation. The areas prone to very high flood risk are with those subbasins. This is categorized into very high flood risk zones, high flood risk zones, moderate flood risk zones, low flood risk zones and finally, no flood risk zones as shown in figure 8. Therefore, it is easier to predict which zone falls within a particular subbasin and we can visualize the flood risk at a time of flood occurrence. Using model in Figure 9, we predict which subbasins can experience very high flood risk example; subbasins number 3,5 and 6 within very high flood risk, 4, 7 and 10 are on high flood risk and so on.

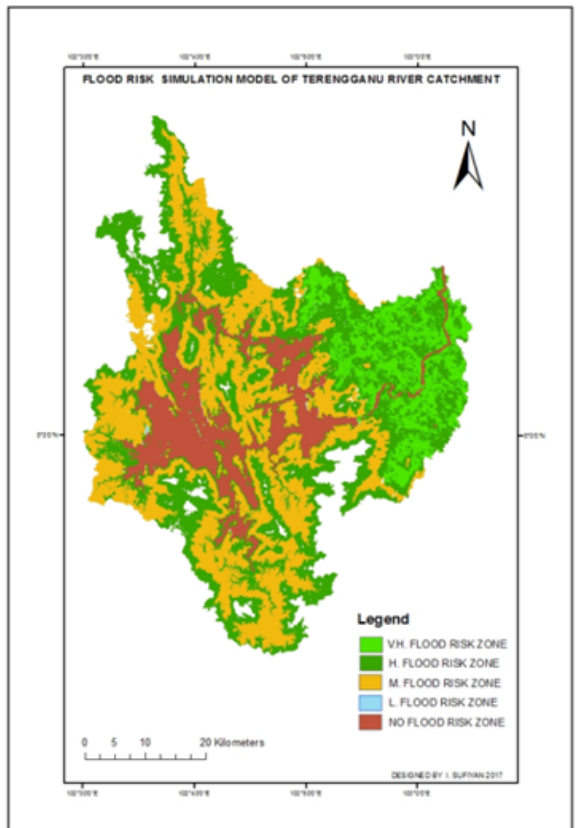

Figure 8: 3D simulation in Terengganu River catchment

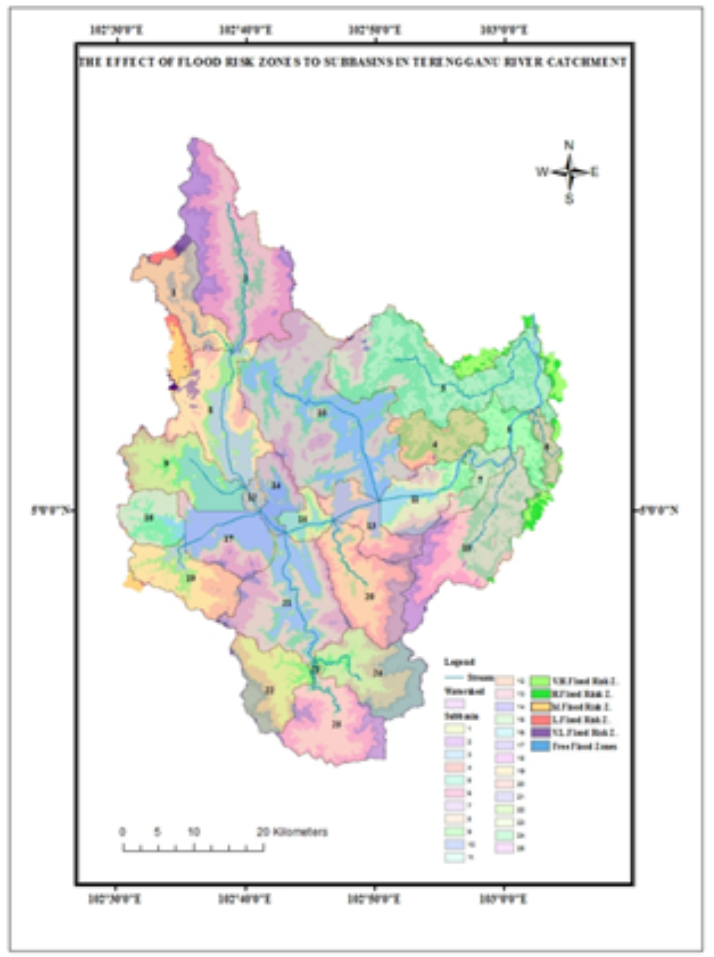

Figure 9: Subbasins flood risk simulation

\section{CONCLUSION}

Other activities that are important to mankind were usually associated with water, and we can always plan to leave near the water for our daily needs. However, we have to recognize the danger or risk involved in settling near the river banks. Notwithstanding, the study of the watershed is not restricted to flood risk assessment along but can also be applied to nutrient supply, sediment yield, plant growths, dam construction, irrigation projects, Lake management as well as for tourism. The Terengganu catchment was harnessed by the development of Artificial Lake Kenyir. Using this 3D model of Terengganu River catchment will help in flood mitigation of future planning and management of the watershed.

\section{ACKNOWLEDGEMENT}

This study was done in collaboration with Dr. Razak Ibn Zakariya, Department of Remote Sensing and GIS, Faculty of Marine and Environmental Science, Universiti Malaysia Terengganu. 
REFERENCES

[1 Tsakiris, G. 2014. Flood risk assessment: concepts, modelling, applications. Natural Hazards and Earth System Sciences, 14 (5), 13-61

[2] Smith, P.J. 2009. Towards the provision of site specific flood warnings using wireless sensor networks, Meteorological Applications, 16, (1), 5764

[3] Tobin, G.A., Montz, B.E. 1997. The impacts of a second catastrophic flood on property values in Linda and Olivehurst, California. Natural Hazards Resource Application Center, University of Colorado, Boulder (http//www. Color. ecu/hazards)

[4] Srivastava, R., Laurian, L. 2006. Natural hazard mitigation in local comprehensive plans: The case of flood, wildfire and drought planning in Arizona, Disaster Prevention and Management, An International Journal, 15, (3), 461-483

[5] Xu, C. 1999. Climate change and hydrologic models: A review of existing gaps and recent research developments, Water Resources Management, 13, (5), 369-382

[6] Schumann, G., Matgen, P., Pappenberger, F. 2008. Conditioning water stages from satellite imagery on uncertain data points, IEEE Geoscience and Remote Sensing Letters, 5, (4), 810-813

[7] Jain, S.K., Saraf, A.K., Goswami, A., Ahmad, T. 2006. Flood inundation mapping using NOAA AVHRR data, Water Resources Management, 20, (6), 949-959

[8] Patel, D.P., Srivastava, P.K. 2013. Flood hazards mitigation analysis using remote sensing and GIS: correspondence with town planning scheme, Water Resources Management, 27, (7), 2353-2368

[9] Mitchell, J.K. 2003. European river floods in a changing world, Risk Analysis, 23, (3), 567-574

[10] Sanders, B.F. 2007. Evaluation of on-line DEMs for flood inundation modeling, Advances in Water Resources, 30, (8), 1831-1843

[11] Cobby, D.M., Mason, D.C., Davenport, I.J. 2001. Image processing of airborne scanning laser altimetry data for improved river flood modelling, ISPRS J. Photogrammetry and Remote Sensing, 56, (2), 121138

[12] Wang, Y., Colby, J.D., Mulcahy, K.A. 2002. An efficient method for mapping flood extent in a coastal floodplain using Landsat TM and DEM
[13] Srivastava, P.K., Mukherjee, S., Gupta, M., Singh, S.K. 2011. Characterizing monsoonal variation on water quality index of River Mahi in India using geographical information system, Water Quality, Exposure and Health., 2, (3-4), 193-203

[14] Büchele B. 2006. Flood-risk mapping: contributions towards an enhanced assessment of extreme events and associated risks, Natural Hazards and Earth System Sciences, 6, (4), 485-503

[15] Tunstall, S.M., Johnson, C.L., Penning-Rowsell, E.C. 2004. Flood hazard management in England and Wales: from land drainage to flood risk management, in World Congress on Natural Disaster Mitigation, 1921.

[16] Dutta, D., Herath, S., Musiake, K.A. 2003. Mathematical model for flood loss estimation, Journal of Hydrology, 277, (1), 24-49

[17] Pistrika, A., Tsakiris, G., Nalbantis, I. 2014. Flood depth-damage functions for built environment, Environmental. Processes, 1, (4), 553572

[18] Arnold, J.G. 2012. SWAT: Model use, calibration, and validation, Trans. ASABE, 55, (4), 1491-1508

[19] Martz, L.W., J. Garbrecht, J. 1992. Numerical definition of drainage network and subcatchment areas from digital elevation models, Computers and Geosciences, 18, (6), 747-761

[20] Arabi, M., Govindaraju, R.S., Hantush, M.M. 2007. A probabilistic approach for analysis of uncertainty in the evaluation of watershed management practices, Journal of Hydrology, 333, (2), 459-471

[21] Narasimhan, B., Srinivasan, R., Arnold, R.J.G., M. Di Luzio, M. 2005. Estimation of long-term soil moisture using a distributed parameter hydrologic model and verification using remotely sensed data, Transactions of the ASAE, 48, (3), 1101-1113

[22] Zope, P.E., Eldho, T.I., Jothiprakash, V. 2015. Impacts of urbanization on flooding of a coastal urban catchment: a case study of Mumbai City, India, Natural Hazards, 75, (1), 887-908

[23] Marghany, M., Hashim, M. 2012. 3-D Front Reconstruction from Radarsat-1 SAR Data

[24] Marghany, M., Ibrahim, Z., Van Genderen, J. 2002. Azimuth cut-off model for significant wave height investigation along coastal water of Kuala Terengganu, Malaysia, International Journal of Applied Earth Observation Geoinformation, 4, (2), 147-160 